\title{
Approaches and constraints to the reconstruction of palaeoproductivity from Cape Basin abyssal benthic foraminifera (South Atlantic)
}

\author{
Paula Diz ${ }^{1 *}$ \& Stephen Barker ${ }^{2}$ \\ ${ }^{1}$ Department of Geociencias Marinas y Ordenación del Territorio, Facultad de Ciencias del Mar, Universidad de Vigo, Campus \\ Lagoas-Marcosende, 36310, Vigo, Spain \\ ${ }^{2}$ School of Earth and Ocean Science, Cardiff University, Cardiff C10 3AT, UK \\ *Correspondence: pauladiz@uvigo.es
}

\begin{abstract}
The characteristics of benthic foraminiferal assemblages from well-oxygenated deep-sea settings have been used to reconstruct past productivity conditions. None of the different approaches that have been developed is without complications or applies in all settings. In this study we assess the use of benthic foraminifera (accumulation rates and assemblages composition) as proxies for palaeoproductivity changes during the last glacial period $(25-95 \mathrm{ka})$ in an abyssal core located in the south of Cape Basin $\left(41.1^{\circ} \mathrm{S}, 7.8^{\circ} \mathrm{E}, 4981 \mathrm{~m}\right.$ water depth). Assemblage characteristics indicate a generally food-limited environment receiving episodic inputs of labile organic carbon of variable strength. High seasonality in the delivery of organic material to the seafloor in the form of phytodetritus influences the assemblage characteristics because the corresponding response does not involve the whole community. Benefiting from this occasionally high organic input is the opportunistic species Epistominella exigua (Brady) that reproduces rapidly to build up large populations. In general, the rest of the species (i.e. less opportunistic compared to E. exigua) show only subtle variations in their population densities and fauna composition. Under those circumstances benthic foraminiferal accumulation rates seem to be independent of the amount of organic flux arriving at the sediment surface and respond instead to the strength of phytoplankton blooms.
\end{abstract}

Keywords: benthic foraminifera; palaeoproductivity; seasonality; abyssal; phytodetritus

Received 10 December 2015; accepted 27 February 2016

The fossil record of benthic foraminifera has been widely used as a proxy for past environmental conditions (for reviews see Gooday 2003; Murray 2006; Jorissen et al. 2007; Gooday \& Jorissen 2012). Despite the complexity of factors playing a role in foraminiferal distribution and the effect of post-depositional processes (Murray 2001; Jorissen et al. 2007), there is a general agreement that benthic foraminifera from deep-sea environments largely respond to a few parameters: the organic carbon flux, bottom-water hydrodynamics (and related grain size), bottom- and pore-water oxygenation and carbonate saturation (see reviews in Mackensen et al. 1995; Jorissen et al. 2007). Within these parameters, the estimation of past changes in the primary production (and organic carbon flux to the seafloor) from benthic foraminifera has received major attention in palaeoceanographic studies because of the implications of changes in the biological pump on past and future climate. Based on knowledge of the ecology of benthic foraminifera, a number of studies have suggested the abundance of benthic foraminifera (benthic foraminiferal accumulation rates, Herguera \& Berger 1991), the contribution of different foraminiferal morphotypes (Corliss \& Chen 1988) and species composition (e.g. Altenbach et al. 1999) as quantitative and qualitative proxies for past organic carbon fluxes arriving at the seafloor. Faunal composition might also provide information about the quality (refractory v. labile) of the organic carbon (e.g. Fontanier et al. 2005). The input of labile organic carbon to the seafloor derived from seasonal or episodic phytoplankton blooms at the surface also influences assemblage composition (e.g. Smart et al. 1994; Sun et al. 2006) and diversity (e.g. Corliss et al. 2009; Gooday et al. 2010, 2012; Enge et al. 2011) so providing information about the periodicity of the organic carbon flux.

Evaluating the extent to which benthic foraminifera can be used to infer a particular set of past environmental conditions and understanding the complicating factors and limitations of such reconstructions is fundamental to advancing the use of proxy methods based on these organisms. In this study we discuss palaeoenvironmental inferences based on benthic foraminiferal assemblage characteristics from an abyssal core located in the south of Cape Basin (South Atlantic). We examine the consistency of the most typical palaeoproductivity proxies by comparing information provided by our assemblages with environmental parameters from independent proxies obtained in the same core and other proxy archives.

\section{Material and methods}

The marine sediment core discussed in this study (TNO57-21) was recovered in the south Cape Basin, slightly north of the Agulhas ridge in the SE Atlantic Ocean $\left(41.1^{\circ} \mathrm{S}, 7.8^{\circ} \mathrm{E}, 4981 \mathrm{~m}\right.$ of water depth, $13.8 \mathrm{~m}$ long, Fig. 1). The site is presently bathed by the poorly ventilated, cold and fresh Antarctic Bottom Water (AABW). The location lies below the Subtropical Convergence (STC) front that separates the cold low-salinity subantarctic waters to the south and warm saline subtropical waters to the north. The complex interaction of physico-chemical factors associated with cross-frontal mixing of subantarctic and subtropical waters and the intense turbulence and eddy activity (Llido et al. 2004; Baker-Yeboah et al. 2010) result in relatively elevated pulses or episodes of primary production in the surface waters of the study area (Froneman et al. 1997; Machu et al. 2005).

Several previous micropalaeontological studies have been carried out on core TN057-21. The palaeoceanographic significance of planktonic foraminifera assemblages are discussed in Barker et al. (2009, 2010) and Barker \& Diz (2014). The linkages between the 


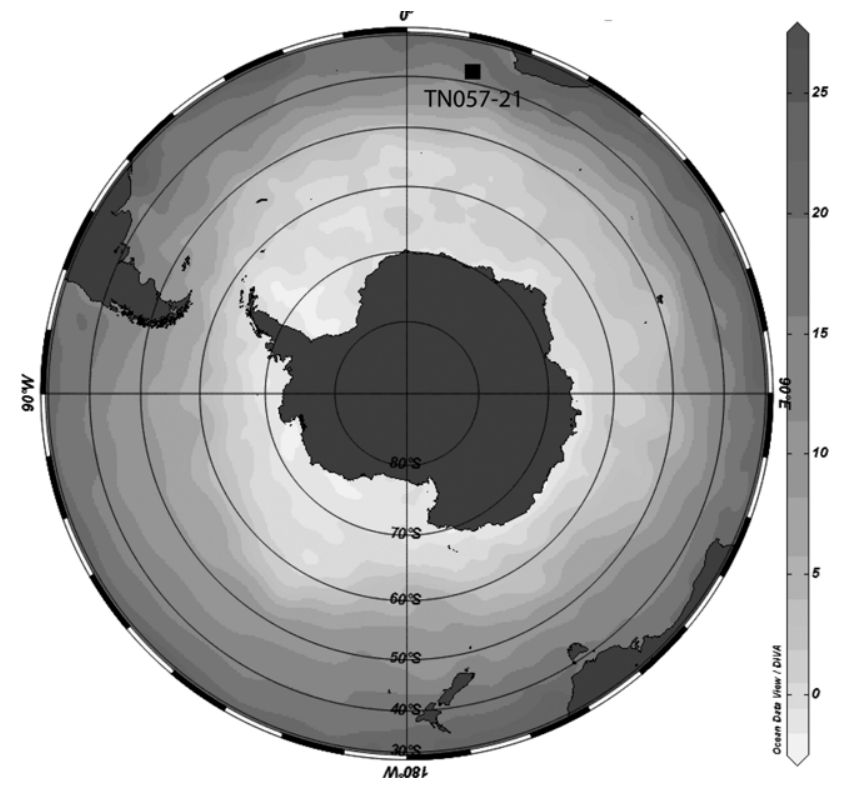

Fig. 1. Location of core TN057-21 in the South Atlantic Southern Ocean (map elaborated using Ocean Data View, Schlitzer, R., http://odv.awi.de, 2015). Detailed information about modern hydrography and primary productivity patterns can be found in Llido et al. (2004) and Machu et al. (2005). record of the benthic foraminifera Epistominella exigua and millennial-scale climate variability during the last $95 \mathrm{ka}$ are considered in Diz \& Barker (2015). However, detailed information about benthic assemblage composition from c. 25 to $95 \mathrm{ka}$, and relevant additional palaeoenvironmental information, were beyond the scope of these earlier papers and are therefore addressed in the present study. The age model used in this study is described in Barker \& Diz (2014) and the methods for the study of benthic fauna are indicated in Diz \& Barker (2015). Briefly, foraminifera are picked from the $>125 \mu \mathrm{m}$ fraction, mounted on faunal slides and identified following the generic assignations of Loeblich \& Tappan (1987) and published illustrations (see Table 1). The study of benthic foraminifera in the $>125 \mu \mathrm{m}$ size fraction potentially underestimates the abundance of small $(63-125 \mu \mathrm{m})$ opportunistic taxa such as Alabaminella weddellensis (Earland) which are typically abundant in areas characterized by episodic phytoplankton blooms (e.g. Thomas et al. 1995; Diz et al. 2007; Smart et al. 2010). On the other hand, it allows for studying a feasible number of samples still showing major faunal patterns (e.g. Poli et al. 2012; Schönfeld et al. 2012). Raw counts can be found in Diz \& Barker (2015) and the most characteristic species of benthic foraminifera are illustrated in this study (Fig. 2). The assemblages are largely dominated by Epistominella exigua ( $>40 \%$ on average), a phytodetritus-related species. In order to assess the ecological significance of the other relevant species we discuss the

Table 1. Ecological attributions of the most characteristic benthic foraminiferal species in core TNO57-21

\begin{tabular}{|c|c|c|}
\hline Species & Microhabitat & Ecological significance \\
\hline \multicolumn{3}{|l|}{ Low flux } \\
\hline $\begin{array}{l}\text { Fontbotia wuellerstorfi } \\
\text { (Schwager)=Anomalina } \\
\text { wuellerstorfi Schwager. See } \\
\text { Phleger et al. (1953, pl. 11, figs } \\
\text { 1-2) and this work, Fig 2:8. }\end{array}$ & $\begin{array}{l}\text { Epifaunal/ } \\
\text { Epibenthic }\end{array}$ & $\begin{array}{l}\text { Fontbotia wuellerstorfi is an epibenthic species (Linke \& Lutze 1993) that lives in well-oxygenated and } \\
\text { ventilated bottom waters away from high productivity coastal environments. Global distributional } \\
\text { patterns indicate that it prefers organic fluxes below } 2 \mathrm{~g} \mathrm{~cm}^{-2} \mathrm{a}^{-1} \text { (Altenbach et al. 1999). In the South } \\
\text { Atlantic, the distribution of this species coincides with relatively sustained food fluxes in areas where } \\
\text { carbonate dissolution is not too severe (Mackensen et al. 1995). In deep-sea sediments of the Indian } \\
\text { Ocean } F \text {. wuellerstorfi co-occurs with the phytodetritus species E. exigua. On an ocean-wide scale it co- } \\
\text { occurs with Uvigerina peregrina (a typical high-flux species) on the lower range of organic carbon } \\
\text { fluxes of the latter (Altenbach et al. 1999). This information suggests that } F \text {. wuellerstorfi is adapted to a } \\
\text { wide range of environmental conditions, including a strongly pulsed supply of organic carbon in the } \\
\text { Indian Ocean (Gupta 1997; De \& Gupta 2010). }\end{array}$ \\
\hline
\end{tabular}

Low flux

Oridorsalis umbonatus (Reuss) Shallow $=$ Rotalina umbonata Reuss. See infaunal Smith (1964, pl. 4, fig. 8 as Pseudoeponides umbonatus) and this work (Fig. 2:15). Most of the individuals found in core TN057-21 are juvenile forms.

Low flux

Pyrgo murrhina (Schwager) =Biloculina murrhina

Schwager. See Phleger et al. (1953, pl. 5, figs $22-24)$

Low flux

Globocassidulina subglobosa $($ Brady $)=$ Cassidulina subglobosa Brady. See Parker (1958, pl. 4, fig. 13) and this work (Fig. 2:10).

Epifaunal

Epifaunal/ Infaunal
On an ocean-wide scale, $O$. umbonatus seems to be distributed in areas receiving low organic carbon fluxes (Altenbach et al. 1999). Mackensen et al. (1995) suggest that the distribution of O. umbonatus in the South Atlantic is related to relatively well-oxygenated pore waters receiving a relatively low but sustained food supply. It co-occurs with E. exigua in the carbonate-supersaturated and low organic carbon areas of the Weddell Sea continental shelf (Mackensen et al. 1990). In the eastern Indian Ocean, Murgese \& De Deckker (2005) found the assemblage composed by $O$. umbonatus-E. exigua and $P$. murrhina indicator of low organic carbon. In Sulu area, Miao \& Thunell (1993) indicated O. umbonatus as a species inhabiting shallow infaunal low organic carbon, well-oxygenated sediments in agreement with Rathburn \& Corliss (1994). Likewise, Burke et al. (1993) include O. umbonatus together with Eggerella bradyi within the group of low productivity species in the central Pacific. Conversely Gupta (1997) interprets the group of O. umbonatus, Eggerella bradyi and Melonis pompilioides as reflecting intermediate flux of relatively degraded organic matter and Kaiho (1999) considers O. umbonatus as an indicator of low-oxygen conditions.

Pyrgo murrhina is an epifaunal species (Corliss \& Chen 1988) found in areas of low organic carbon fluxes (Altenbach et al. 1999) and high oxygenation, such as the South Central Indian Ocean (De \& Gupta 2010) or eastern Indian Ocean (Murgese \& De Deckker 2005). Conversely, Gupta \& Thomas (2003) interpret the abundance of $P$. murrhina in Indian cores as related to pulsed food and good carbonate preservation.

In the North Atlantic, Sun et al. (2006) found an inverse correlation of the G. subglobosa-N. umbonifera assemblage with seasonality of the organic matter. In the SE Atlantic, this species characterizes sandy sediments of the Walvis Ridge (South Atlantic) with low organic carbon and high calcium carbonate content and enhanced bottom current velocities (Schmiedl et al. 1997). However, G. subglobosa has been associated with deposition of phytodetritus in the NE Atlantic Abyssal Plain (Gooday 1988, 1993), NW Africa (Eberwein \& Mackensen 2006) and the Antarctic shelf (Suhr et al. 2003). 
Table 1. (Continued)

\begin{tabular}{|c|c|c|}
\hline Species & Microhabitat & Ecological significance \\
\hline \multicolumn{3}{|l|}{ Episodic phytoplankton blooms } \\
\hline $\begin{array}{l}\text { Epistominella exigua (Brady) } \\
=\text { Pulvinulina exigua Brady. See } \\
\text { Lobegeier \& Sen Gupta ( } 2008, \\
\text { pl. I, fig. } 18 \text { ) and this work } \\
\text { (Fig. } 2: 9) .\end{array}$ & $\begin{array}{r}\text { Epifaunal/ } \\
\text { Shallow } \\
\text { infaunal }\end{array}$ & $\begin{array}{l}\text { This is an opportunistic species that rapidly colonizes and feeds on aggregates of phytodetritus produced } \\
\text { by episodic phytoplankton blooms (e.g. Gooday 1988, 1993; Cornelius \& Gooday 2004; Sun et al. } \\
\text { 2006; Gooday et al. 2010). Epistominella exigua is well adapted to oligotrophic conditions well away } \\
\text { from areas where the productivity is high and the flux of organic matter is continuous (Mackensen et al. } \\
\text { 1995). In the eastern South Atlantic, E. exigua is found in association with F. wuellerstorfi in low organic } \\
\text { carbon areas on the flanks of the Walvis Ridge (Schmiedl et al. 1997). It is also abundant in the deep } \\
\text { western South Atlantic (Harloff \& Mackensen 1997), the deep Weddell Sea continental slope (Anderson } \\
\text { 1975; Cornelius \& Gooday 2004) and SW Indian Ocean (Corliss 1983; Peterson 1983). }\end{array}$ \\
\hline
\end{tabular}

Pullenia osloensis Feyling-

Hanssen. See Diz et al. (2007, supplementary information, $\mathrm{pl}$. II, fig. 5) and this work (Fig. 2:16).

Not very well constrained Shallow to deep infaunal
Intermediate flux

Melonis zaandamae (Van

Voothuysen $)=$ Melonis

barleeanum var. zaandamae

van Voorthuysen. See

Mackensen et al. (1993, pl. 3,

figs 4-5) and this work

(Fig. 2:13).

Intermediate flux

Siphotextularia rolshauseni

Phleger and Parker. See Phleger et al. (1953, pl. 5, fig. 7) and this work (Fig. 2:2).
Shallow
infaunal

Not well constrained

sip

Siphotextularia rolshauseni is an agglutinated species composed of calcareous fragments of various sizes and it is considered a junior synonym of Siphotextularia catenata Cushman (Corliss 1979; Nees \& Struck 1994). There are a few references to this species in superficial sediments of the North Atlantic (see review in Nees \& Struck 1994), SW Pacific (Kurihara \& Kennett 1986), South China Sea (Szarek et al. 2006) and the Indian Ocean (Corliss 1979, Nees 1997). Similarly, this species is reported as rare in South Atlantic superficial sediments by Mackensen et al. (1993, Siphotextularia sp.), Schmiedl et al. (1997, S. catenata) as well as in Pleistocene and Miocene sediments of the Walvis Ridge (Boltovskoy \& Boltovskoy 1989).

Nees \& Struck (1994) and Struck (1995) relate the occurrence of S. rolshauseni in the GreenlandNorwegian Sea during MIS 2 with a period of low trophic quality. This interpretation is also suggested by the downcore distribution of S. rolshauseni in core TNO57-21 which peaks together with Melonis spp. during MIS 4 (see text).

The species belonging to the so-called 'Lagenina group' are found as rare representatives of the living and recently dead assemblages in different marine settings. Thus, the ecological significance of this group is not well constrained. Some of the species belonging to the Lagenina group are illustrated in Figure 2: Fissurina staphyllearia (Fig. 2:3), Lagena hispidula (Fig. 2:5), Oolina globosa (Fig. 2:4); Parafissurina felsinea (Fig. 2:6).

\footnotetext{
Wide flux range? is composed of several species belonging to the genus

Amphycorina, Bifarilaminella, Cushmanina, Fissurina,

Homaloedra, Lagena, Oolina,

Palliolatella, Parafissurina and

Procerolagena
}

The so-called 'Lagenina group' Unknown
Melonis spp. species (in this core mainly M. zaandamae) are intermediate infaunal foraminifera that tolerate moderate oxygen depletion (Fontanier et al. 2002). Melonis spp. is generally associated with intermediate organic carbon flux and refractory organic matter (Caralp 1989; Alve 2010). Mackensen et al. $(1993,1995)$ refer to the assemblage comprising Melonis pompiloides, M. zaandamae and $O$. umbonatus as South Atlantic deep-sea high productivity fauna. the South Cape Basin (Boltovskoy \& Boltovskoy 1989), SW Indian Ocean (Corliss 1979) and the Agulhas retroflection area (Diz et al. 2007). Most authors interpret the group of Pullenia spp. (mainly Pullenia bulloides) as an indicator of areas of high organic supply (Rasmussen et al. 2003) or high but Epistominella exigua with Pullenia osloensis and Pullenia salisburyi as secondary species is considered an indicator of low to intermediate organic flux and high seasonality (Gupta \& Thomas 2003). flux regimes (from low to intermediate) and organic carbon qualities (i.e. labile and refractory). Pullenia salisburyi is also present in core TNO57-21 (Fig. 2:17) even though its relative contributions are lower than P. osloensis.

\begin{abstract}
by episodic phytoplankton blooms (e.g. Gooday 1988, 1993; Cornelius \& Gooday 2004; Sun et al. western South Atlantic (Harloff \& Mackensen 1997), the deep Weddell Sea continental slope (Anderson
\end{abstract} (1) 


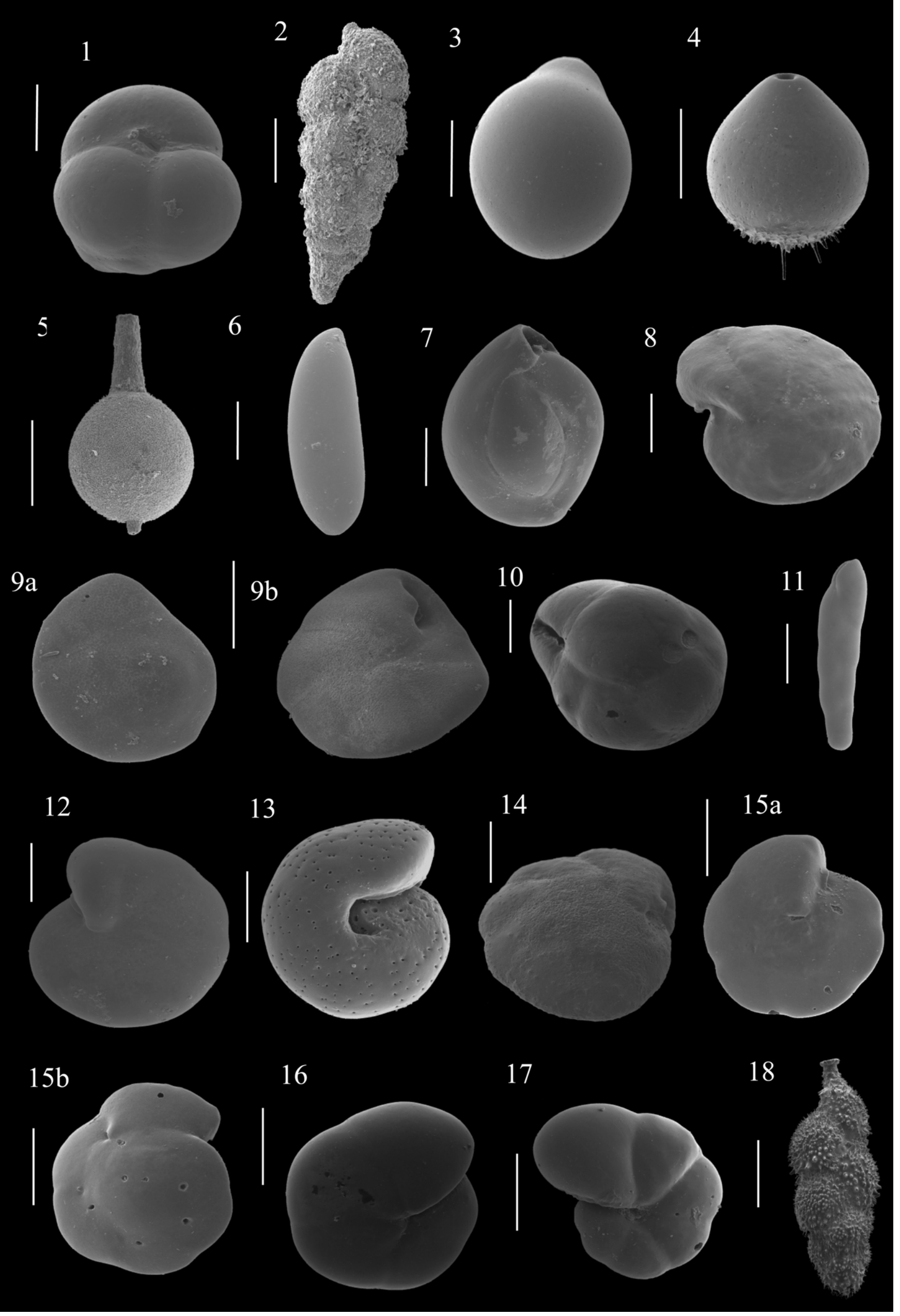




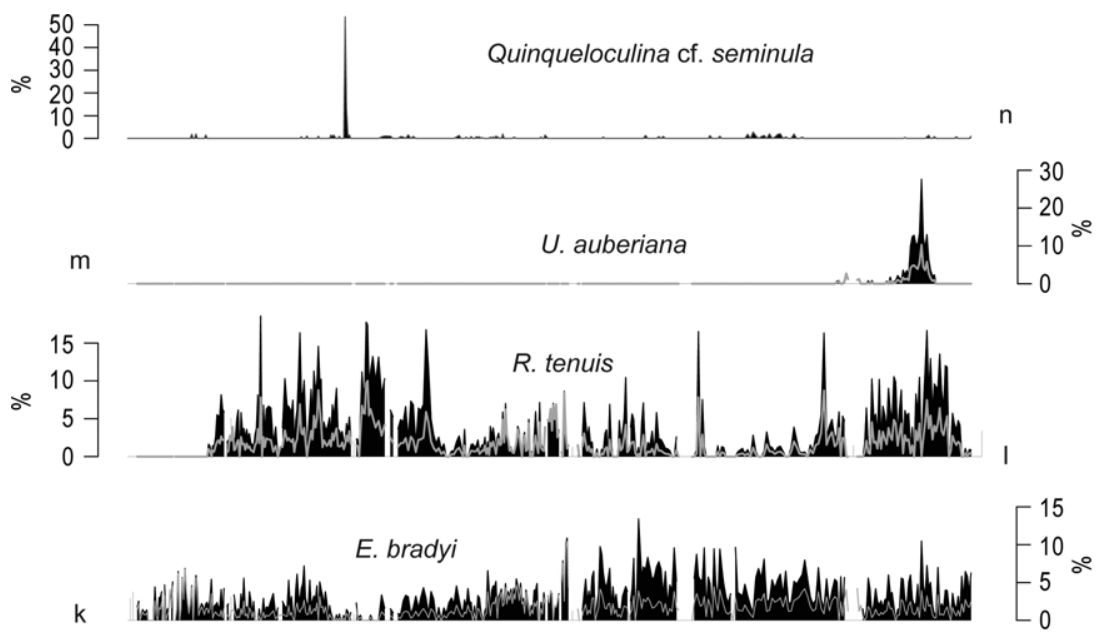

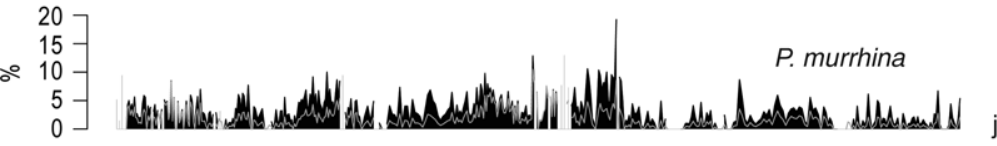
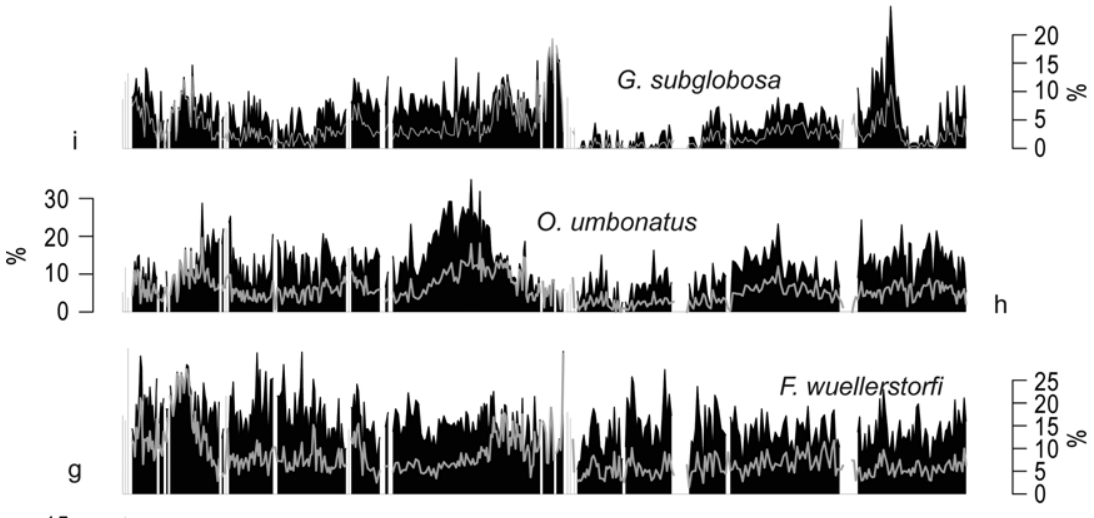

$\left.\therefore \begin{array}{r}15 \\ 10 \\ 5 \\ 0\end{array}\right]$ Melonis spp.
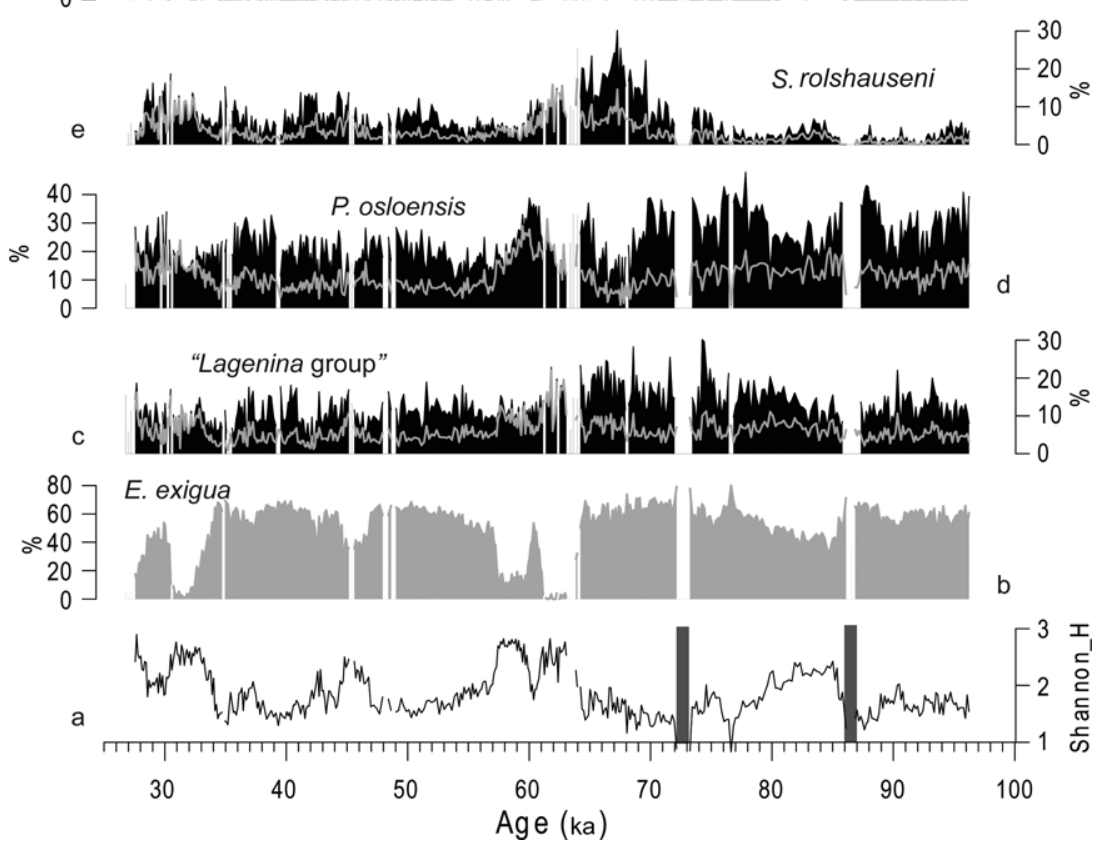

Fig. 3. Benthic foraminiferal assemblages in core TN057-21. (a) Shannon-H diversity index; (b) the relative abundance of Epistominella exigua; $(\mathbf{c}-\mathbf{n})$ the most characteristic species of benthic foraminifera in core TNO57-21. Percentages are shown in the total assemblage (grey line) and in the phytodetritus-free assemblages (black filled area). Percentages are calculated on the basis of samples containing $>50$ specimens and unaffected by dissolution. Intensely dissolved intervals that correspond to Greenland Stadials 19 and 21 are indicated by vertical bars in (a). The ecological preferences for the most characteristic benthic foraminiferal species or group of species are summarized in Table 1 .

Fig. 2. 1. Eggerella bradyi (Cushman). 2. Siphotextularia rolshauseni Phleger \& Parker. 3. Fissurina staphyllearia Schwager. 4. Oolina globosa (Montagu). 5. Lagena hispidula Cushman. 6. Parafissurina felsinea (Fornasini). 7. Quinqueloculina cf. seminula (Linnaeus). 8. Fontbotia wuellerstorfi (Schwager). 9. Epistominella exigua (Brady), (a) spiral side, (b) umbilical side. 10. Globocassidulina subglobosa (Brady), scale bar $200 \mu \mathrm{m} .11$. Rutherfordoides tenuis (Phleger \& Parker), scale bar $200 \mu \mathrm{m}$. 12. Gyroidinoides cf. polius. 13. Melonis zaandamae (Van Voorthuysen). 14. Nutallides umbonifera (Cushman). 15. Oridorsalis umbonatus (Reuss), (a) umbilical side, (b) spiral side. 16. Pullenia osloensis Feyling-Hanssen. 17. Pullenia salisburyi Stewart \& Stewart. 18. Uvigerina auberiana d'Orbigny, scale bar $200 \mu \mathrm{m}$. Scale bars $100 \mu \mathrm{m}$ unless noted otherwise. 

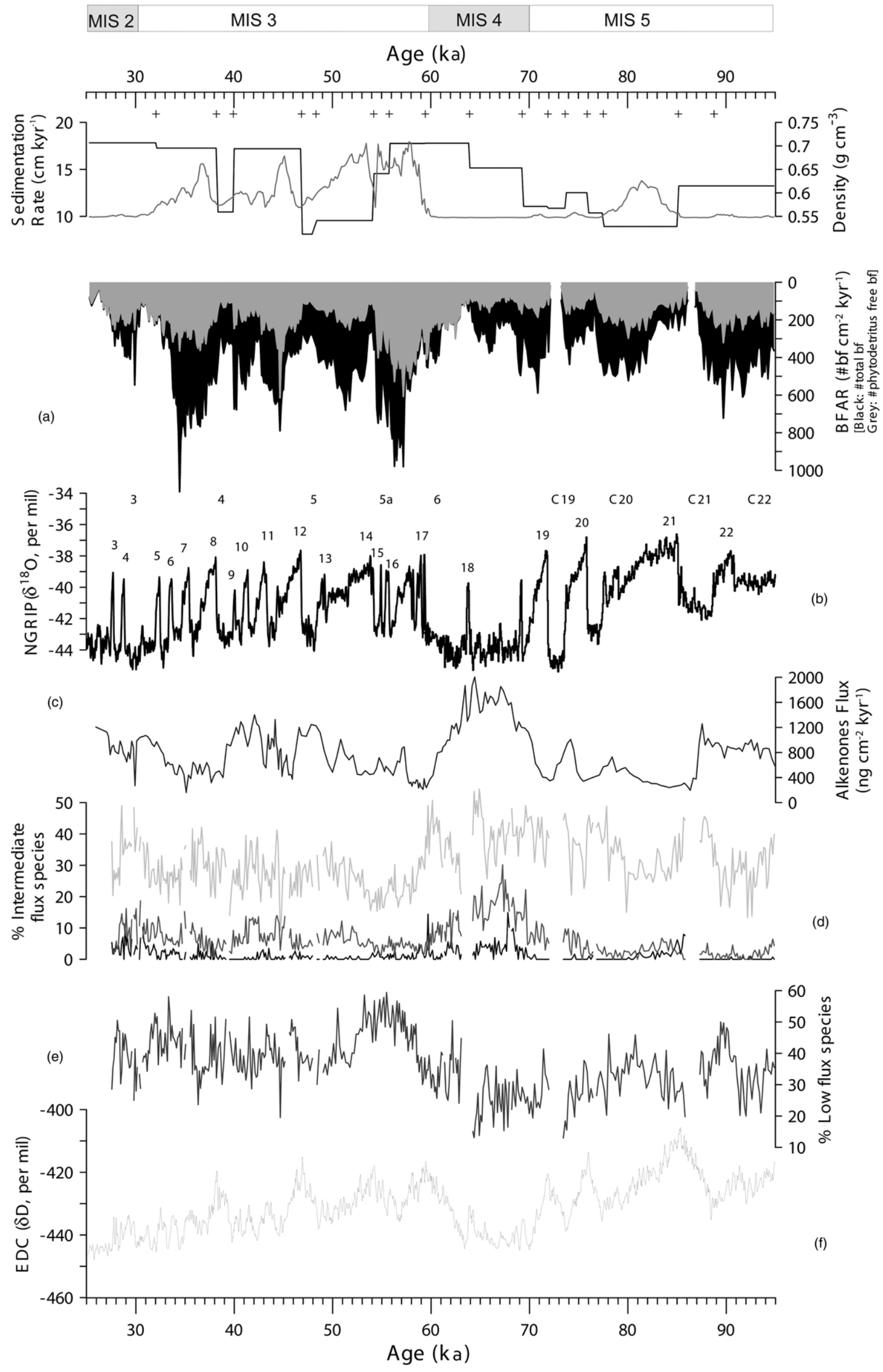
multiple proxies (e.g. $\%$ of coarse fraction, $\% \mathrm{CaCO}_{3}$, foraminiferal abundances, composition of assemblages) it was indicated that carbonate dissolution does not seem to exert an overall control on benthic abundance or species distribution with the exception of the Holocene (not considered in this study) and Greenland Stadial (GS) events GS19 and 21. Those poorly preserved periods (indicated in Fig. 3 by bars) are characterized by a low percentage of calcium carbonate, very low foraminiferal abundances and a low number of benthic taxa. They are not used to infer palaeoenvironmental conditions (see detailed discussion in Diz \& Barker 2015). The comparison of the composition of the 'dissolved assemblages' with modern samples (Mackensen et al. 1993) indicates that Nutallides umbonifera (Cushman) is very rare along core TNO57-21 (see Fig. 2). Nutallides umbonifera is generally related to corrosive bottom waters in the South Atlantic (Mackensen et al. 1993; Harloff \& Mackensen 1997; Schmiedl et al. 1997). It might suggest that other factors more than carbonate undersaturated waters are playing a role in this species distribution (i.e. oligotrophic conditions and absence of phytodetritus deposition, Smart \& Gooday 1997; Kurbjeweit et al. 2000; Carman \& Keigwin 2004).

\section{Results}

The foraminifera fauna of core TNO57-21 comprises 39 benthic species dominated by calcareous forms. The Shannon-H diversity index averages 1.9 (Fig. 3a). High diversity values occur when the relative contribution of the dominant phytodetritus-related species Epistominella exigua (Brady) is diminished. The averaged relative contribution of this species is as high as $47 \%$ (Fig. 3b). Other, relatively common species are Pullenia osloensis (FeylingHanssen) (average percentage $11.9 \%$, Fig. 3d), Oridorsalis umbonatus (Reuss) (6\%, Fig. 3h), Fontbotia wuellerstorfi (Schwager) (7.9\%, Fig. $3 \mathrm{~g}$ ) and the group of species belonging to the suborder Lagenina called the 'Lagenina group' (see Table 1, $11.9 \%$, Fig. 3 c). Secondary calcareous species $(<10 \%$ on average $)$ showing high abundances at particular intervals are Pyrgo murrhina (Schwager) (Fig. 3j), Globocassidulina subglobosa (Brady) (Fig. 3i), Melonis spp. (comprising M. zaandamae (Van Voothuysen), Melonis pompilioides (Fichtel \& Moll) and Melonis sp., Fig. 3f) and Rutherfordoides tenuis (Phleger \& Parker) (Fig. 31). Calcareous species with short-lived peaks are Uvigerina auberiana d'Orbigny (Fig. $3 \mathrm{~m}$ ) and Quinqueloculina cf. seminula (Linnaeus) (Fig. 3n). The most characteristic agglutinated foraminifera is the calcareous agglutinated Siphotextularia rolshauseni (Phleger \& Parker, Fig. 3e) with Eggerella bradyi (Cushman) as secondary species (Fig. 3k).

The BFAR values in core TNO57-21 show large fluctuations ranging from 30 to 1100 foraminifera $(>125 \mu \mathrm{m}$ fraction $) \mathrm{cm}^{-2}$ $\mathrm{ka}^{-1}$. On average, peak BFAR values are higher during northern stadial events occurring during MIS 3 than over MIS 5 (Fig. 4a). The lowest BFAR values occur during GS19 and GS21 (also the Holocene, not shown) when benthic foraminiferal dissolution was inferred (Diz \& Barker 2015) and thus they are excluded from interpretation (Fig. 4a). In general, episodes of peak BFAR values are largely driven by the phytodetritus-related species Epistominella exigua (Fig. 4a), and show a tight temporal correspondence with abrupt climate changes occurring in the North Atlantic Ocean and concomitant antiphase response in the South Atlantic (see Fig. 4 and Diz \& Barker 2015). Episodes of high BFAR phfree $_{\text {coincide with }}$ BFAR although they are of much lower magnitude and sharpness (Fig. 4a, grey shaded area). The highest BFAR phfree $_{\text {values coincide }}$ with a single peak in Quinqueloculina cf. seminula (Fig. $3 n$ ) at $c$. $45 \mathrm{ka}$ and near the beginning of MIS 3 (c. 56-58 ka) with high relative abundances of $G$. subglobosa, $F$. wuellerstorfi and $O$. umbonatus (see Fig. 3).

\section{Discussion}

\section{Reconstructing the flux of organic carbon to the seafloor from benthic foraminifera}

\section{Benthic foraminiferal accumulation rates}

The benthic foraminiferal accumulation rate (BFAR, number of foraminifera $\mathrm{cm}^{-2} \mathrm{ka}^{-1}$ ) has been suggested as a palaeoproductivity proxy (Herguera \& Berger 1991; Herguera 1992, 2000). However, several studies indicated that obtaining a quantitative estimation of primary production or export production from BFAR values might be limited by several factors, with the difficulty of obtaining reliable calibrations, carbonate dissolution and taphonomical processes being the most important (see review in Jorissen et al. 2007). In this study no attempts have been made to estimate absolute palaeoproductivity or palaeo-carbon fluxes, but we evaluate the potential use of the calculated BFAR as a semi-quantitative proxy for food supply to the ocean floor (e.g. Thomas et al. 1995; Alegret \& Thomas 2009) in core TNO57-21.

The BFAR values during the Holocene and late deglaciation (not plotted but calculated on the basis of Diz \& Barker (2015) data; $<100$ foraminifera $\mathrm{cm}^{-2} \mathrm{ka}^{-1}$ ) are within the range of values for abyssal core tops from the Pacific open ocean at water depths $>4000 \mathrm{~m}$ likely affected by carbonate dissolution (Herguera \& Berger 1991; Herguera 1992). However, peak BFAR values from MIS 3 to MIS 5 are four to eight times Holocene values (Fig. 4). These accumulation rates are substantially higher than maxima values recorded in core-top samples from widely distributed openocean areas at various depths in the Pacific. Following the use of BFAR as a palaeoproductivity proxy, these results might suggest past increases in the organic carbon flux to the seafloor up to several times the present conditions. According to modern primary production distributions (see Machu et al. 2005, fig. 5) this might be equivalent to a change from oligotrophic subtropical open ocean areas to high productivity upwelling centres (e.g. Benguela upwelling). In fact, peaks of BFAR reach values found in continental shelf areas affected by seasonal upwelling, such as Cape Blanc upwelling (Guichard et al. 1999; Zarriess \& Mackensen 2010) or the SW African upwelling (Schmiedl \& Mackensen 1997). Such a change in the palaeoenvironmental conditions, if it had

\footnotetext{
Fig. 4. Palaeoproductivity from benthic foraminiferal accumulation rates and assemblage composition. (a) The Benthic Foraminiferal Accumulation Rate (BFAR, total number of foraminifera $>125 \mu \mathrm{m} \mathrm{cm}^{-2} \mathrm{ka}^{-1}$ ) is indicated as a shaded black area and Benthic Foraminiferal Accumulation Rate calculated on phytodetritus-free basis (i.e. discounting the contribution of the phytodetritus-related species Epistominella exigua, BFAR phfree is indicated by a grey shaded area. Consequently, the difference between the two shaded areas is the BFAR of E. exigua (BFAR E.exigua ). (b) Northern Hemisphere ice core temperature record (Greenland NGRIP $\delta^{18} \mathrm{O}$; EPICA 2006) is shown as reference. (c) The flux of alkenones (ng cm $\mathrm{cm}^{-2}$ ) in core TNO57-21, a proxy for organic carbon flux to the seafloor (Sachs \& Anderson 2005), plotted on Barker \& Diz (2014) age model. (d) Intermediate-flux species (light grey line) are composed of individuals belonging to P. osloensis, S. rolhsauseni (medium grey line) and Melonis spp. (dark grey line). (e) The group of 'low-flux' species is composed of shallow infaunal O. umbonatus, G. subglobosa and epifaunal P. murrhina and F. wuellerstorfi. Percentages are calculated on the phytodetritus-free assemblage basis. (f) Record of Southern Hemisphere ice core temperature (Antarctica Epica Dome C $\delta D$, Jouzel et al. 2007, 3 points running average) is shown as reference. (b) and (f) are plotted on GICC05/NALPS timescale (Barker et al. 2011). Black crosses at the top of the figure indicate tie points and sedimentation rates, respectively, used in the age model construction and BFAR calculations. The grey line in the top plot shows density values calculated using the model proposed by Sachs \& Anderson (2003).
} 
occurred, would have involved a large change in assemblage composition, i.e. from low productivity faunas (low abundances) to a high productivity assemblage (high BFAR). This seems to be unrealistic considering that assemblage changes are subtle in comparison to BFAR fluctuations (see Figs 3 and 4) and they do not involve the appearance of species related to eutrophic conditions (see next section). In fact, variations in BFAR are mainly driven by the phytodetritus-related species Epistominella exigua (Table 1 and Fig. 4a). In the absence of this species, fluctuations in BFAR $_{\text {phfree }}$ (BFAR phytodetritus-free; 'phfree') are of much lower magnitude and suggest only subtle changes in organic carbon fluxes. This could be explained by the fact that when large quantities of fresh marine organic matter (phytodetritus) are available, even for short periods of time, opportunistic species, such as Epistominella exigua, reproduce rapidly and produce a large number of tests (see Thiel et al. 1989). The accumulation of foraminifera is not related in a predictable manner to organic flux and, in these circumstances, BFAR should not be used as a quantitative (or semiquantitative) proxy (Thomas et al. 1995; Diz et al. 2007; Smart 2008; Zarriess \& Mackensen 2010) for the organic carbon flux reaching the seafloor. BFAR is rather related to the strength of the phytoplankton blooms. The episodic and labile nature of the phytodetritus aggregates reaching the seafloor (Beaulieu 2002; Smith et al. 2008) could explain the weak correlation $(r=-0.24$, $P=0.000, n=467$ ) between BFAR (also $\mathrm{BFAR}_{\text {phfree}}$ ) and the alkenones flux, a proxy for averaged organic carbon flux to the seafloor (Sachs \& Anderson 2003) obtained in the same core (Fig. 4c).

\section{Benthic foraminiferal assemblage composition}

The use of benthic foraminiferal assemblages as palaeoproductivity proxies is based on the relation of faunal composition to organic flux rates (e.g. Morigi et al. 2001). Again, the quantification of flux regimes from the relative abundance of major species is complicated by ecological factors, broad adaptability of some species to organic carbon fluxes and uncertainties related to estimations of carbon flux (Altenbach et al. 1999; Gooday 2003; Jorissen et al. 2007). Thus, the information provided by the faunal composition of core TNO5721 is used here as qualitative proxy for the organic carbon flux or its quality/periodicity.

The relative abundance of particular species or group of species is related qualitatively to the predominance of a particular flux regime (i.e. high, intermediate, low-flux species), quality (i.e. labile, refractory) or seasonality of the flux (i.e. seasonal, sustained). In this study, groups are defined based on representative species with wellknown ecology (see the ecological attributions of characteristic species in Table 1). Because organic flux-dependent patterns should be best analysed within the environmental optimum of species (Altenbach et al. 1999), those species with percentages lower than $10 \%$ for most of the record (e.g. Eggerella bradyi, Quinqueloculina cf. seminula, Rutherfordoides tenuis, see Fig. 2 and 3) and/or those species for whom the ecology is not well constrained are not included in any of the groups. An example of the latter is the high contribution to the assemblage of individuals belonging to the 'Lagenina group' ( $>10 \%$, Fig. 3c, see Fig. 2). Unfortunately their ecology is poorly known (see Table 1) and consequently the contribution to the palaeoenvironmental understanding of the assemblage changes is limited.

The most abundant species throughout the core is Epistominella exigua, an epifaunal/shallow infaunal abyssal deep-sea opportunistic foraminifera that flourishes and rapidly reproduces in the presence of phytodetritus aggregates (see ecological attributions in Table 1). Thus, high relative abundance of E. exigua (Fig. 3b) along core TNO57-21 indicates overall low organic carbon fluxes punctuated by episodic phytoplankton blooms that resulted in the deposition of phytodetrital inputs (i.e. labile organic carbon). This interpretation is supported by the 'phytodetritus-free' assemblage which is composed of species typical of oligotrophic ('low flux') to moderately mesotrophic ('intermediate') environmental conditions.

The 'low-flux species' are the epifaunal Fontbotia wuellerstorfi, Pyrgo murrhina and the shallow infaunal Oridorsalis umbonatus and Globocassidulina subglobosa (see Table 1). All together these represent $>30 \%$ of the phytodetritus-free assemblage (Fig. 4e) reaching up to $60 \%$ during early MIS 3 . For some of these species (i.e. G. subglobosa, F. wuellerstorfi, P. murrhina) a relationship to phytodetritus input (see Table 1) has also been suspected. However, their downcore relative abundance does not covary with BFAR or percentages of the phytodetritus-related species E. exigua (Figs 3b and $4 \mathrm{a}, \mathrm{e}$ ). Instead, they must respond to a different type of phytodetritus or, more likely, they prefer sustained (and low) organic carbon flux to the seafloor rather than pulsed (see also Smart 2008).

The group of species considered indicative of an 'intermediateflux' regime are mainly represented by the relatively common shallow infaunal Pullenia osloensis together with Melonis spp. and Siphotextularia rolshauseni (Fig. 4d and Table 1). Those species show a statistically significant negative correlation $(P<0.000)$ to the relative contribution of the species belonging to the low-flux group $\left(\mathrm{r}_{O}\right.$. umbon-S. rolshaseni $=-0.38 ; \mathrm{r}_{P \text {. osloensis }-P \text {. murrhina }}=-0.39$; $\mathrm{r}_{P .}$ osloensis- $F$. wuellerstorf $i=-0.28 ; \mathrm{r}_{P}$. osloensis - G.subglobosa $=-0.23 ; \mathrm{r}_{O}$. umbonatus-Melonis spp. $=-0.35$ ). The relative contribution of the 'intermediate-flux' group indicates slightly more eutrophic conditions during MIS 5 and MIS 4 than during MIS 3. Peaks of the intermediate-flux fauna occurring over MIS 4 are mainly caused by noticeably increased contributions of Melonis spp. and $S$. rolshauseni (Figs 3e, f and 4d) occurring in coincidence with high relative contribution of Epistominella exigua (Fig. 3b) and the substantial increase in the alkenone flux measured during glacial MIS 4 (Fig. 4c). These two species show affinity for degraded organic carbon (Table 1) suggesting that during MIS 4 part of the sedimentary organic compounds are of low nutritional value. This might be explained by a different type and/or fate of phytodetrital material arriving to the seafloor which could promote the response of species that benefit from the bloom indirectly (i.e. bacteria colonizing aggregates, Koho et al. 2008). In fact, it has been inferred (Diz \& Barker 2015) that slightly different physical conditions promoting phytoplankton blooms in the surface waters occurred during MIS 4/MIS 5 transition and early MIS 4 (seasonality and windiness) than during MIS 3 and late MIS 5 (mainly eddy activity). Notably, that assemblage change does not trigger a parallel increase in the $\mathrm{BFAR}_{\text {phfree }}$ indicating that a change in the food quality does not force a change in the absolute numbers of benthic foraminiferal accumulation rate but only in the assemblage composition.

\section{Constraints and approaches: overview}

Benthic foraminifera (BFAR and assemblage composition) were analysed in abyssal core TN057-21. Episodic phytoplankton blooms represent the main source of 'disturbance' to the benthic environment and have important consequences for the structure and taxonomic composition of the benthic foraminifera record. The inferred phytodetritus deposition does not seem to trigger a response by the whole community but it is limited to a single species, leading to a decrease in the diversity of the assemblages. The species benefiting from phytodetritus input is the opportunistic (r-strategist) Epistominella exigua which reacts quickly, producing high numbers of individuals and consequently high benthic foraminiferal accumulation rates. The response of the remaining fauna (the socalled 'phytodetritus-free assemblage') to phytodetritus input is mainly constrained to a concomitant moderate increase in the 
foraminiferal abundance $\left(\mathrm{BFAR}_{\mathrm{phfree}}\right)$ with overall little variation in the assemblage composition. This could be explained by the different ecological preferences of species with lower reproductive potential (k-strategists) and likely benefiting from other types of organic carbon (less labile). All these data together suggest BFAR could not be a reliable proxy for palaeoproductivity in abyssal (food-limited) environments when benthic foraminifera are highly dependent on the rate and nature of the input of labile organic material generated in the euphotic zone. Under these circumstances fluctuations in BFAR do not reflect the flux of organic carbon to the seafloor but rather the strength of phytoplankton blooms in the surface waters. In this case, the assemblage composition is relevant for interpreting palaeoenvironmental conditions.

\section{Acknowledgements and Funding}

Authors wish to thank the reviewers Christopher Smart and Andrew Gooday for their suggestions that improved the manuscript. This work was supported by the UK Natural Environment Research Council NE/J008133/1 and R+D contract CO-078-10 (Ref. UVigo). PD was supported by Xunta de Galicia (Programa Investigadores Isidro Parga Pondal) and University of Vigo (Programa Retención de Talento 2015)

\section{Scientific editing by Laia Alegret}

\section{References}

Alegret, L. \& Thomas, E. 2009. Food supply to the seafloor in the Pacific Ocean after the Cretaceous/Paleogene boundary event. Marine Micropaleontology, 73, 105-116.

Altenbach, A.V., Pflaumann, U., Schiebel, R., Thies, A., Timm, S. \& Trauth, M. 1999. Scaling percentages and distributional patterns of benthic foraminifera with flux rates of organic carbon. Journal of Foraminiferal Research, 29, $173-185$.

Alve, E. 2010. Benthic foraminiferal responses to absence of fresh phytodetritus: A two-year experiment. Marine Micropaleontology, 76, 67-75.

Anderson, J.B. 1975. Factors controlling $\mathrm{CaCO}_{3}$ dissolution in the Weddell Sea from foraminiferal distribution patterns. Marine Geology, 19, 315-332.

Baker-Yeboah, S., Byrne, D.A. \& Watts, D.R. 2010. Observations of mesoscale eddies in the South Atlantic Cape Basin: Baroclinic and deep barotropic eddy variability. Journal of Geophysical Research: Oceans, 115(C12), C12069, http://doi.org/10.1029/2010jc006236

Barker, S. \& Diz, P. 2014. Timing of the descent into the last Ice Age determined by the bipolar seesaw. Paleoceanography, 29, 489-507, http://doi.org/10 1002/2014PA002623

Barker, S., Diz, P., Vautravers, M.J., Pike, J., Knorr, G., Hall, I.R. \& Broecker, W S. 2009. Interhemispheric Atlantic seesaw response during the las deglaciation. Nature, 457, 1097-1102.

Barker, S., Knorr, G., Vautravers, M.J., Diz, P. \& Skinner, L.C. 2010. Extreme deepening of the Atlantic overturning circulation during deglaciation. Nature Geoscience, 3, 567-571.

Barker, S., Knorr, G. et al. 2011. 800,000 years of abrupt climate variability. Science, 334, 347-351.

Beaulieu, S.E. 2002. Accumulation and fate of phytodetritus on the sea floor Oceanography and Marine Biology Annual Review, 40, 171-232.

Boltovskoy, E. \& Boltovskoy, D. 1989. Paleocene-Pleistocene benthic foraminiferal evidence of major paleoceanographic events in the eastern South Atlantic (DSDP Site 525, Walvis Ridge). Marine Micropaleontology, 14, 283-316.

Burke, S.K., Berger, W.H., Coulbourn, W.T. \& Vincent, E. 1993. Benthic foraminifera in box core ERDC 112, Ontong Java Plateau. Journal of Foraminiferal Research, 23, 19-39, http://doi.org/10.2113/gsjfr.23.1.19

Caralp, H.M. 1989. Abundance of Bulimina exilis and Melonis barleeanum relationship to the quality of marina organic matter. Geo-Marine Letters, 9 $37-43$.

Carman, M.R. \& Keigwin, L.D. 2004. Preservation and color differences in Nuttallides umbonifera. Journal of Foraminiferal Research, 34, 102-108.

Corliss, B.H. 1979. Recent deep-sea benthonic foraminiferal distributions in the southeast Indian Ocean: Inferred bottom-water routes and ecological implications. Marine Geology, 31, 115-138.

Corliss, B.H. 1983. Distribution of Holocene deep-sea benthonic foraminifera in the southwest Indian Ocean. Deep Sea Research Part A, Oceanographic Research Papers, 30, 95-117.

Corliss, B.H. \& Chen, C. 1988. Morphotype patterns of Norwegian Sea deep-sea benthic foraminifera and ecological implications. Geology, 16, 716-719.

Corliss, B.H., Brown, C.W., Sun, X. \& Showers, W.J. 2009. Deep-sea benthic diversity linked to seasonality of pelagic productivity. Deep Sea Research Part I: Oceanographic Research Papers, 56, 835-841.

Cornelius, N. \& Gooday, A.J. 2004. 'Live' (stained) deep-sea benthic foraminiferans in the western Weddell Sea: trends in abundance, diversity and taxonomic composition along a depth transect. Deep Sea Research Part II: Topical Studies in Oceanography, 51, 1571-1602.

De, S. \& Gupta, A.K. 2010. Deep-sea faunal provinces and their inferred environments in the Indian Ocean based on distribution of Recent benthic foraminifera. Palaeogeography, Palaeoclimatology, Palaeoecology, 291, 429-442.

Diz, P. \& Barker, S. 2015. Linkages between rapid climate variability and deep-sea benthic foraminifera in the deep Subantarctic South Atlantic during the last 95 kyr. Paleoceanography, 30, 601-611, http://doi.org/10.1002/ 2015PA002784

Diz, P., Hall, I.R., Zahn, R. \& Molyneux, E.G. 2007. Paleoceanography of the southern Agulhas Plateau during the last $150 \mathrm{ka}$ : Inferences from benthic foraminiferal assemblages and multispecies epifaunal carbon isotopes. Paleoceanography, 22, PA4218, http://doi.org/10.1029/2007PA001511

Eberwein, A. \& Mackensen, A. 2006. Regional primary productivity differences off Morocco (NW Africa) recorded by modern benthic foraminiferal and their stable carbon isotopic composition. Deep-Sea Research I, 53, 1379-1405.

Enge, A.J., Nomaki, H. et al. 2011. Response of the benthic foraminiferal community to a simulated short-term phytodetritus pulse in the abyssal North Pacific. Marine Ecology Progress Series, 438, 129-142.

EPICA, Community \& Members 2006. One-to-one coupling of glacial climate variability in Greenland and Antarctica. Nature, 444, 195-198.

Fontanier, C., Jorissen, F.J., Licari, L., Alexandre, A., Anschutz, P. \& Carbonel, P. 2002. Live benthic foraminiferal faunas from the Bay of Biscay: faunal density, composition, and microhabitats. Deep-Sea Research I, 49, 751-785.

Fontanier, C., Jorissen, F.J., Chaillou, G., Anschutz, P., Grémare, A. \& Griveaud, C. 2005. Live foraminiferal faunas from a $2800 \mathrm{~m}$ deep lower canyon station from the Bay of Biscay: Faunal response to focusing of refractory organic matter. Deep-Sea Research I, 52, 1189-1227.

Froneman, P.W., Perissinotto, R. \& Pakhomov, E.A. 1997. Biogeographical structure of the microphytoplankton assemblages in the region of the Subtropical Convergence and across a warm-core eddy during austral winter. Journal of Plankton Research, 19, 519-531.

Gooday, A.J. 1988. A response by benthic Foraminifera to the deposition of phytodetritus in the deep sea. Nature, 332, 70-73.

Gooday, A.J. 1993. Deep-sea benthic foraminiferal species which exploit phytodetritus: Characteristic features and controls on distribution. Marine Micropaleontology, 22, 187-205.

Gooday, A.J. 2003. Benthic foraminifera (protista) as tools in deep-water palaeoceanography: Environmental influences on faunal characteristics. In Southward, A.J., Tyler, P.A., Young, C.M. \& Fuiman, L.A. (eds) Advances in Marine Biology. Academic Press, London, 1-90.

Gooday, A.J. \& Jorissen, F.J. 2012. Benthic foraminiferal biogeography: controls on global distribution patterns in deep-water settings. Annual Review of Marine Science, 4, 237-262.

Gooday, A.J., Malzone, M.G., Bett, B.J. \& Lamont, P.A. 2010. Decadal-scale changes in shallow-infaunal foraminiferal assemblages at the Porcupine Abyssal Plain, NE Atlantic. Deep Sea Research Part II: Topical Studies in Oceanography, 57, 1362-1382.

Gooday, A.J., Bett, B., Jones, D. \& Kitazato, H. 2012. The influence of productivity on abyssal foraminiferal biodiversity. Marine Biodiversity, $\mathbf{4 2}$, $1-17$.

Guichard, S., Jorissen, F. \& Peypouquet, J.P. 1999. Late Quaternary benthic foraminiferal records testifying lateral variability of the Cape Blanc upwelling signal. Comptes Rendus de l'Academie de Sciences - Serie IIa: Sciences de la Terre et des Planetes, 329, 295-301, http://doi.org/10.1016/S1251-8050(99) 80249-3

Gupta, A.K. 1997. Paleoceanographic and paleoclimatic history of the Somali Basin during the Pliocene-Pleistocene; multivariate analyses of benthic foraminifera from DSDP Site 241 (Leg 25). Journal of Foraminiferal Research, 27, 196-208.

Gupta, A.K. \& Thomas, E. 2003. Initiation of Northern Hemisphere glaciation and strengthening of the northeast Indian monsoon: Ocean drilling program site 758, eastern equatorial Indian Ocean. Geology, 31, 47-50.

Harloff, J. \& Mackensen, A. 1997. Recent benthic foraminifera associations and ecology of the Scotia Sea and Argentine Basin. Marine Micropaleontology, 31, 1-29.

Herguera, J.C. 1992. Deep-sea benthic foraminifera and biogenic opal: Glacial to postglacial productivity changes in the western equatorial Pacific. Marine Micropaleontology, 19, 79-98

Herguera, J.C. 2000. Last glacial paleoproductivity patterns in the eastern equatorial Pacific: benthic foraminifera records. Marine Micropaleontology, 40, 259-275.

Herguera, J.C. \& Berger, W.H. 1991. Paleoproductivity from benthic foraminifera abundance: Glacial to postglacial change in the west-equatorial Pacific. Geology, 19, 1173-1176.

Jorissen, F.J., Fontanier, C. \& Thomas, E. 2007. Paleoceanographical proxies based on deep-sea benthic foraminiferal assemblage characteristics. In Claude, H.M. \& Anne De, V. (eds) Developments in Marine Geology, vol. 1. Elsevier, 263-325.

Jouzel, J., Masson-Delmotte, V. et al. 2007. Orbital and millennial Antarctic climate variability over the past 800,000 years. Science, 317, 793-796.

Kaiho, K. 1999. Effect of organic carbon flux and dissolved oxygen on the benthic foraminiferal oxygen index (BFOI). Marine Micropaleontology, 37, 67-76. 
Koho, K.A., Langezaal, A.M., van Lith, Y.A., Duijnstee, I.A.P. \& van der Zwaan, G.J. 2008. The influence of a simulated diatom bloom on deep-sea benthic foraminifera and the activity of bacteria: A mesocosm study. Deep-Sea Research I, 55, 696-719.

Kurbjeweit, F., Schimiedl, G., Schiebel, R., Hemleben, C., Pfannkuche, O., Wallmann, K. \& Schäfer, P. 2000. Distribution, biomass and diversity of benthic foraminifera in relation to sediment geochemistry in the Arabian Sea. Deep-Sea Research II, 47, 2913-2955.

Kurihara, K. \& Kennett, J.P. 1986. Neogene benthic foraminifers: distribution in depth traverse, southwest Pacific. In: Kennett, J.P., von der Borch, C.C. et al. (eds) Initial Reports of the Deep Sea Drilling Project, 90(2). US Government Printing Office, Washington, DC, 1037-1077.

Linke, P. \& Lutze, G.F. 1993. Microhabitat preferences of benthic foraminifera a static concept or a dynamic adaptation to optimize food acquisition? Marine Micropaleontology, 20, 215-234.

Llido, J., Machu, E., Sudre, J., Dadou, I. \& Garçon, V. 2004. Variability of the biological front south of Africa from SeaWiFS and a coupled physicalbiological model. Journal of Marine Research, 62, 595-609.

Lobegeier, M.K. \& Sen Gupta, B.K. 2008. Foraminifera of hydrocarbon seeps, Gulf of Mexico. Journal of Foraminiferal Research, 38, 93-116.

Loeblich, A.R. \& Tappan, H. 1987. Foraminifera Genera and Their Classification. Van Nostrand Reinhold, New York.

Machu, E., Biastoch, A., Oschlies, A., Kawamiya, M., Lutjeharms, J.R.E. \& Garçon, V. 2005. Phytoplankton distribution in the Agulhas system from a coupled physical-biological model. Deep-Sea Research Part I: Oceanographic Research Papers, 52, 1300-1318.

Mackensen, A., Grobe, H., Kuhn, G. \& Fütterer, D.K. 1990. Benthic foraminiferal assemblages from the eastern Weddell Sea between 68 and $73^{\circ} \mathrm{S}$ : Distribution, ecology and fossilization potential. Marine Micropaleontology, 16, 241-283.

Mackensen, A., Fütterer, D.K., Grobe, H. \& Schmiedl, G.E.P. 1993. Benthic foraminiferal assemblages from the eastern South Atlantic Polar Front region between $35^{\circ}$ and $57^{\circ} \mathrm{S}$ : Distribution, ecology and fossilization potential. Marine Micropalentology, 22, 33-69.

Mackensen, A., Schmiedl, G., Harloff, J. \& Giese, M. 1995. Deep-sea foraminifera in the South Atlantic Ocean: Ecology and assemblage composition. Micropaleontology, 41, 342-358.

Miao, Q. \& Thunell, R.C. 1993. Recent deep-sea benthic foraminiferal distributions in the South China and Sulu Seas. Marine Micropaleontology, 22, $1-32$.

Morigi, C., Jorissen, F.J., Gervais, A., Guishard, S. \& Borsetti, A.M. 2001. Benthic foraminiferal faunas in surface sediments off NW Africa: Relationship with organic flux to the ocean floor. Journal of Foraminiferal Research, 31, $350-368$.

Murgese, D.S. \& De Deckker, P. 2005. The distribution of deep-sea benthic foraminifera in core tops from the eastern Indian Ocean. Marine Micropaleontology, 56, 25-49.

Murray, J.W. 2001. The niche of benthic foraminifera, critical thresholds and proxies. Marine Micropaleontology, 41, 1-7.

Murray, J.W. 2006. Ecology and Applications of Benthic Foraminifera. Cambridge University Press, Cambridge.

Nees, S. 1997. Late Quaternary palaeoceanography of the Tasman Sea: The benthic foraminiferal view. Palaeogeography, Palaeoclimatology, Palaeoecology, 131, 365-389.

Nees, S. \& Struck, U. 1994. The biostratigraphic and paleoceanographic significance of Siphotextularia rolshauseni Phleger and Parker in NorwegianGreenland Sea sediments. Journal of Foraminiferal Research, 24, 233-240.

Paillard, D., Labeyrie, L. \& Yiou, P. 1996. Macintosh program performs time-series analysis. Eos, Transactions of the American Geophysical Union, 77, 379.

Parker, F.L. 1958. Eastern Mediterranean Foraminifera. Reports of the Swedish Deep Sea Expedition, 8, 217-283.

Peterson, L.C. 1983. Recent abyssal benthic foraminiferal biofacies of the Eastern Equatorial Indian Ocean. Marine Micropaleontology, 8, 479-519.

Phleger, F.B., Parker, F.L. \& Peirson, J.F. 1953. North Atlantic foraminifera. Reports of the Swedish Deep Sea Expedition, 7, 1-122.

Poli, M.S., Meyers, P.A., Thunell, R.C. \& Capodivacca, M. 2012. Glacialinterglacial variations in sediment organic carbon accumulation and benthic foraminiferal assemblages on the Bermuda Rise (ODP Site 1063) during MIS
13 to 10. Paleoceanography, 27, PA3216, http://doi.org/10.1029/2012pa 002314

Rasmussen, T.L., Oppo, D.W., Thomsen, E. \& Lehman, S.J. 2003. Deep sea records from the southeast Labrador Sea: Ocean circulation changes and icerafting events during the last 160,000 years. Paleoceanography, 18, 1018, http://doi.org/10.1029/2001PA000736

Rathburn, A.E. \& Corliss, B.H. 1994. The ecology of living (stained) deep-sea benthic foraminifera from the Sulu Sea. Paleoceanography, 9, 87-150, http:// doi.org/10.1029/93PA02327

Sachs, J.P. \& Anderson, R.F. 2003. Fidelity of alkenone paleotemperatures in southern Cape Basin sediment drifts. Paleoceanography, 18, 1082, http://doi. org $/ 10.1029 / 2002 \mathrm{pa} 000862$

Sachs, J.P. \& Anderson, R.F. 2005. Increased productivity in the Subantarctic Ocean during Heinrich events. Nature, 434, 1118-1121.

Schmiedl, G. \& Mackensen, A. 1997. Late Quaternary paleoproductivity and deep water circulation in the eastern South Atlantic Ocean: Evidence from benthic foraminifera. Palaeogeography, Palaeoclimatology, Palaeoecology, 130, 43-80.

Schmiedl, G., Mackensen, A. \& Müller, P.J. 1997. Recent benthic foraminifera from the eastern South Atlantic Ocean: Dependence on food supply and water masses. Marine Micropaleontology, 32, 249-287.

Schönfeld, J., Alve, E., Geslin, E., Jorissen, F., Korsun, S. \& Spezzaferri, S. 2012. The FOBIMO (FOraminiferal BIo-MOnitoring) initiative - Towards a standardised protocol for soft-bottom benthic foraminiferal monitoring studies. Marine Micropaleontology, 94-95, 1-13.

Smart, C.W. 2008. Abyssal NE Atlantic benthic foraminifera during the last 15 kyr: Relation to variations in seasonality of productivity. Marine Micropaleontology, 69, 193-211.

Smart, C.W. \& Gooday, A.J. 1997. Recent benthic foraminifera in the abyssal Northeast Atlantic Ocean; relation to phytodetrital inputs. Journal of Foraminiferal Research, 27, 85-92.

Smart, C.W., King, S.C., Gooday, A.J., Murray, J.W. \& Thomas, E. 1994. A benthic foraminiferal proxy of pulsed organic matter paleofluxes. Marine Micropaleontology, 23, 89-99.

Smart, C.W., Waelbroeck, C., Michel, E. \& Mazaud, A. 2010. Benthic foraminiferal abundance and stable isotope changes in the Indian Ocean sector of the Southern Ocean during the last 20kyr: Paleoceanographic implications. Palaeogeography, Palaeoclimatology, Palaeoecology, 297, 537-548.

Smith, P.B. 1964. Ecology of benthonic species: A discussion of depth distribution of Foraminifera and ecologic factors off El Salvador, including a comparison with other Pacific coast areas. US Government Printing Office, Washington.

Smith, C.R., De Leo, F.C., Bernardino, A.F., Sweetman, A.K. \& Arbizu, P.M 2008. Abyssal food limitation, ecosystem structure and climate change. Trends in Ecology \& Evolution, 23, 518-528.

Struck, U. 1995. Stepwise postglacial migration of benthic foraminifera into the abyssal northeastern Norwegian Sea. Marine Micropaleontology, 26, 207-213.

Suhr, S.B., Pond, D.W., Gooday, A.J. \& Smith, G.R. 2003. Selective feeding by benthic foraminifera on phytodetritus on the western Antarctic Peninsula shelf: evidence from fatty acid biomarker analysis. Marine Ecology Progress Series, 262, 153-162.

Sun, X., Corliss, B.H., Brown, C.W. \& Showers, W.J. 2006. The effect of primary productivity and seasonality of deep-sea benthic foraminifera in the North Atlantic. Deep-Sea Research I, 53, 28-47.

Szarek, R., Kuhnt, W., Kawamura, H. \& Nishi, H. 2006. Distribution of Recent benthic foraminifera along continental slope of the Sunda Shelf (South China Sea). Marine Micropaleontology, 71, 41-59.

Thiel, H., Pfannkuche, O. et al. 1989. Phytodetritus on the deep-sea floor in a central oceanic region of the Northeast Atlantic. Biological Oceanography, 6, 203-239.

Thomas, E., Booth, L., Maslin, M. \& Shackleton, N.J. 1995. Northeastern Atlantic benthic foraminifera during the last 45,000 years: Changes in productivity seen from the bottom up. Palaeoceanography, 10, 545-562.

Zarriess, M. \& Mackensen, A. 2010. The tropical rainbelt and productivity changes off northwest Africa: A 31,000-year high-resolution record. Marine Micropaleontology, 76, 76-91. 